\title{
Disappearing Blue Mussels - Can Mesopredators Be Blamed?
}

\author{
Hartvig Christie ${ }^{1 *}$, Patrik Kraufvelin ${ }^{2 \dagger}$, Lucinda Kraufvelin ${ }^{3}$, Niklas Niemi ${ }^{3}$ and Eli Rinde ${ }^{1}$ \\ ${ }^{1}$ Norwegian Institute for Water Research (NIVA), Oslo, Norway, ${ }^{2}$ Department of Aquatic Resources, Institute of Coastal \\ Research, Swedish University of Agricultural Sciences, Öregrund, Sweden, ${ }^{3}$ Department of Environmental and Marine \\ Biology, Åbo Akademi University, Turku, Finland
}

OPEN ACCESS

Edited by:

Massimo Ponti,

University of Bologna, Italy

Reviewed by:

Britas Klemens Eriksson,

University of Groningen, Netherlands

Kjell Larsson,

Linnaeus University, Sweden

Christian Buschbaum,

Alfred Wegener Institute, Helmholtz

Centre for Polar and Marine Research

(AWI), Germany

*Correspondence:

Hartvig Christie

hartvig.christie@niva.no

tORCID:

Patrik Kraufvelin

orcid.org/0000-0003-3224-8388

Specialty section:

This article was submitted to

Marine Ecosystem Ecology,

a section of the journal

Frontiers in Marine Science

Received: 25 February 2020

Accepted: 16 June 2020

Published: 07 July 2020

Citation:

Christie $\mathrm{H}$, Kraufvelin $\mathrm{P}$, Kraufvelin L, Niemi N and Rinde $E$ (2020) Disappearing Blue Mussels -

Can Mesopredators Be Blamed?

Front. Mar. Sci. 7:550

doi: 10.3389/fmars.2020.00550
Despite many theories, the recent evident decreases in blue mussel (Mytilus edulis) abundance in southern Norway and western Sweden (eastern North Sea) have not yet been explained. To test the possible role of increased predation, an ongoing mesocosm experiment exploring general effects of two mesopredators on the structure of littoral macroalgal and macrofaunal communities was used. These mesopredators were the green crab (Carcinus maenas) and the goldsinny wrasse (Ctenolabrus rupestris) which were distributed in a crossed manner to 12 large mesocosms containing diverse rocky shore communities. For the purposes of this study, boulders covered with recently recruited blue mussels and barnacles (Balanus improvisus) from a natural shore were brought in to the mesocosms during two seasons (August and October), and the coverage of the animals (just blue mussels in summer, both mussels and barnacles in autumn) was registered repeatedly over $24 \mathrm{~h}$. The mussels were rapidly consumed by crabs and wrasses, whereas high survival was recorded on boulders in the controls without predators. The barnacles were only eaten by the crabs and not before most of the mussels had been consumed. As both the green crab and the goldsinny wrasse have been reported to increase in abundance, probably related to overfishing of top predators, the resulting higher predation pressure on especially small blue mussels (recruits) may contribute to the mussel decline along these temperate rocky shores.

Keywords: blue mussel disappearance, predation, mesopredator release, green crabs, wrasses

\section{INTRODUCTION}

During the last years, there has been a concern about decreasing abundances of the blue mussel Mytilus edulis in coastal waters of southern Norway and western Sweden (Skagerrak and eastern North Sea) that has been reported by both scientists and people collecting mussels for recreational purposes (Andersen et al., 2016; Frigstad et al., 2018; Lundström, 2020). The blue mussel has also become much harder to locate at long-term monitoring stations for contaminants in southern Norway (Green et al., 2018). Increased Mytilus spp. mortality have in other countries been linked to diseases, climate change, habitat disruption, and predation (e.g., Rilov and Schiel, 2006; van der Heide et al., 2014; Eggermont et al., 2017; Seuront et al., 2019), but so far the causes for the reduction of Mytilus abundance in Skagerrak have not been clarified. The same factors mentioned above in international studies, including hybridisation between the three occurring Mytilus species, have been suggested as potential causes of M. edulis losses in South Norway. At the southeast coast of Norway, Brooks and Farmen (2013) found M. edulis to be the only species, whereas the rarer 
Mytilus trossulus and Mytilus galloprovincialis were found at other parts (and downstream) along the Norwegian coast, which contradicts the hybridisation theory at least for the south-eastern part of the coast. Observations of high mussel abundance on ropes in harbors and normal recruitment and growth in mussel farms do not support the disease/parasite theory, nor a negative role of higher water temperatures. However, the ropes can serve as refuges from some sort of predation, in particular from mobile benthic species. Thus, the observations of high mussel abundances on ropes support an increased predation pressure as being a potential cause of reduced $M$. edulis populations.

The general efficiency of predators in reducing mussel abundance is well known since the study by Paine (1966) in his highly cited paper. The efficiency of sea stars as blue mussel predators has been documented in southern Norway (Christie, 1983). Further, Elner (1978) showed the role of crabs and Peteiro et al. (2010) the role of fish predation for reducing blue mussel abundance, while Rilov and Schiel (2006) found increasing populations of both labrid fish and crabs to reduce mussel abundance.

During the last decades, the coastal ecosystems in Skagerrak have undergone dramatic changes (Weijerman et al., 2005; Moy and Christie, 2012; Östman et al., 2016). As a response to the drastic reduction in abundance of the top predator coastal cod, Gadus morhua (Cardinale and Svedäng, 2004; Baden et al., 2012), several mesopredators have increased considerably in abundance (mesopredator release sensu Prugh et al., 2009) posing an increased predation risk. Small fish and crustacean predators have been reported to increase in rocky shore ecosystems; typical examples of species that have become more common is the goldsinny wrasse (Ctenolabrus rupestris) (Gjøseter and Paulsen, 2004; Bergström et al., 2016 and references therein) and the green crab (Carcinus maenas) (Eriksson et al., 2011; Infantes et al., 2016). To test possible effects of increasing densities of these two mesopredators on mussels, a sudden intense recruitment of blue mussels in JulyAugust 2019, in both the inner and outer Oslofjord, were used by taking advantage of an ongoing large mesocosm experiment. This was a long-term experiment running from June to October, and the mussel experiments were initiated as short-term add-on experiments in these mesocosms. To test how these two mesopredators directly affect blue mussels, boulders with attached mussels were simply transplanted into the 12 controlled mesocosms. A new, less intense recruitment event in October 2019 allowed repetition of the summer experiment in autumn and testing the mesopredator impact on both mussels and barnacles.

\section{MATERIALS AND METHODS}

At NIVA's research station Solbergstrand by the Oslofjord in southeastern Norway, rocky shore mesocosm experiments have been carried out in 12 large outdoor concrete basins, each containing $12 \mathrm{~m}^{3}$ of seawater (see Figure 1A). The mesocosms are $4.75 \times 3.65 \mathrm{~m}$ at surface level and $1.3 \mathrm{~m}$ deep at high tide. Diverse shore ecosystems based on seaweeds and associated macrofauna have been established over several years. These mesocosms are supplied with a continuous flow of $4 \mathrm{~m}^{3} \mathrm{~h}^{-1}$ of seawater from $1 \mathrm{~m}$ depth in the fjord and they are equipped with wave machines and tidal regulation. For further description of the mesocosms, see Bokn et al. (2003) and Kraufvelin et al. (2006a,b, 2010, 2020). In 2019, the project CRABFISH started in early June and ended in mid-October, being set up for testing predatory top-down effects by the goldsinny wrasse (C. rupestris) and the green crab (C. maenas) on the entire seaweed ecosystem. The mesocosms were distributed among four treatments; three mesocosms did not receive any predators ("Control"), three mesocosms were allocated 50 green crabs each ("Crabs," i.e., ca 4 crabs per $\mathrm{m}^{2}$ bottom area or $\mathrm{m}^{3}$ of water), three mesocosms were assigned 50 wrasses each ("Fish," i.e., the same fish density as for crabs), and the three remaining mesocosms received 50 green crabs and 50 wrasses each ("CrabFish," i.e., ca 4 crabs and 4 fishes per $\mathrm{m}^{2}$ bottom area or $\mathrm{m}^{3}$ of water). Population densities of C. maenas (Moksnes, 2002) and wrasse (Gjøsæter, 2002; Skiftesvik et al., 2014) are hardly quantified in the field, but found to vary over short distances. However, Sayer et al. (1993) reported a density of 4 individuals per $\mathrm{m}^{2}$ of goldsinny wrasse to be high. The density of crabs and fishes remained at the initial level throughout the study (own recordings), but some crabs were observed to climb out of the mesocosms at night and migrated randomly to neighboring mesocosms (extending the meaning of the word walkover). To maintain the three control mesocosms and the three fish-only mesocosms without crabs, the mesopredators occurring in wrong mesocosms had to be caught regularly using baited traps and put back into the nearest Crab or CrabFish mesocosms. Despite these efforts, an effect of crabs on blue mussel cover was observed in the "Control" mesocosms in the August experiment (one crab attacking mussels in each of two control mesocosms).

In late July, high abundance of small $M$. edulis (shell length $2-3 \mathrm{~mm}$ ) was observed in the shallow coastal areas outside the research station at Solbergstrand, covering cobblestones, boulders, seaweeds and seagrass blades. Twelve stones (cobbles/boulders, see Wentworth scale), with a flat top surface area of about $25 \times 30 \mathrm{~cm}$ were collected from the fjord and one boulder was transplanted into each of the mesocosms in early August. The initial blue mussel cover (i.e., percent cover at the top surface of the boulder) and cover of mussels at short (h) time intervals up to $24 \mathrm{~h}$, were estimated to the nearest $5 \%$ by snorkeling in the mesocosms (trying not to disturb the predators). Pictures were taken along with the snorkeling for controlling the cover estimates (see Figure 1B). Ahead of each cover estimate, the amount of mesopredatory crabs and wrasses on and adjacent to each blue mussel boulder was counted.

Later in August, the fjord population of the blue mussels had disappeared (own observations by snorkeling), but a new recruitment event was observed in early October, although less intense with a resulting lower blue mussel density/cover than in August. Hence, it was possible to repeat the experiment in October. This time, 72 stones, each with a top surface area of ca. $10 \times 15 \mathrm{~cm}$ were collected from the same site at Solbergstrand as in August, and six stones were transplanted into each mesocosm. 

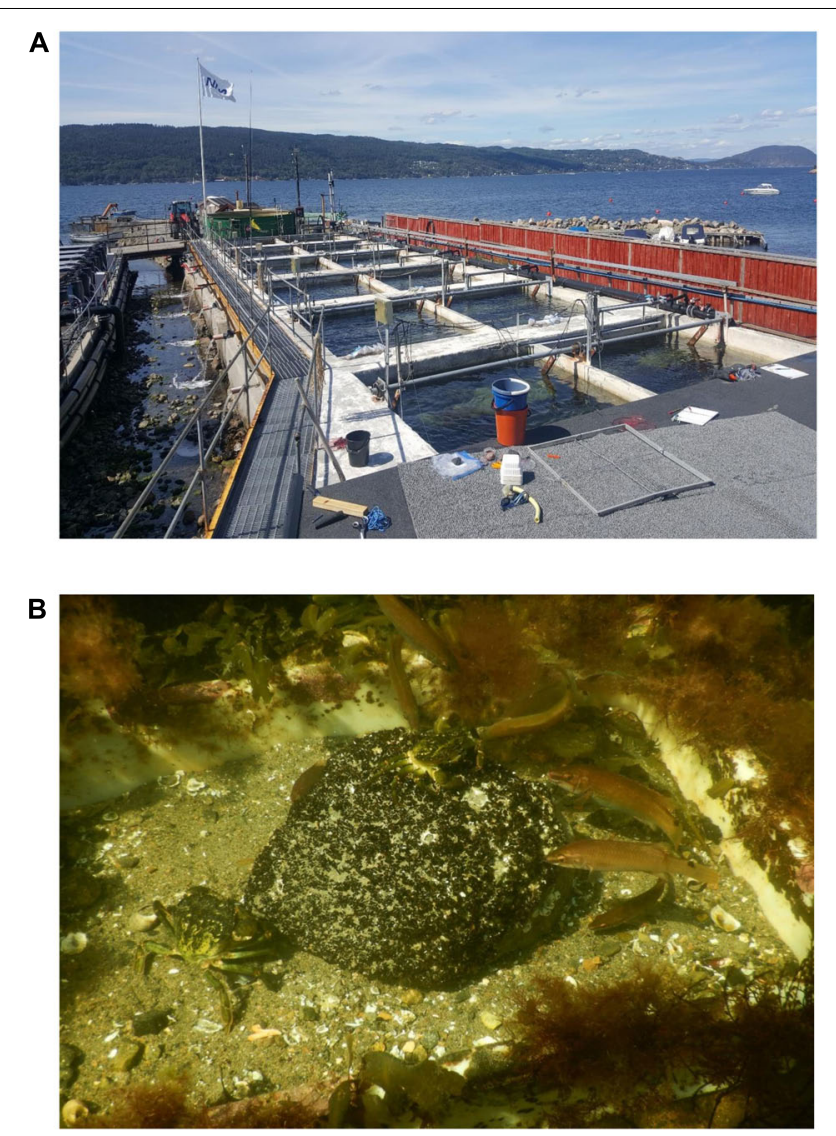

FIGURE 1 | Images showing an overview of the 12 mesocosms at NIVAs Research Station at the Oslofjord (A), and an example of green crabs and goldsinny wrasses attacking a stone with juvenile mussels (B).

The initial cover and the cover of mussels at short time intervals up to $24 \mathrm{~h}$ were estimated as above. The blue mussels in October 2019 were of the same size as those in August 2019. Because crabs were observed eating barnacles (Balanus improvisus) attached to the lower parts of the stones, after they had eaten the mussels in August, the percent cover of barnacles on the stones was also estimated in the October experiment. Unfortunately, there were no resources available for taking action to perform well-designed field experiments using e.g., cages for those two settlement occasions, as the settlements came unexpected.

The differences in the development of mussel and barnacle cover between treatments were analyzed with generalized additive models (GAM, Wood, 2011). Cover was used as response variable and time and treatment as explanatory variables. The model included interaction between the two explanatory variables (time and treatment), and allowed a different smooth for each treatment level, using treatment as the "by" variable in the R-package mgcv (Wood, 2011). The analysis was done in $\mathrm{R}$ (version 3.5.2, $\mathrm{R}$ Core Team, 2019). Wald tests of the significance of each parametric and smooth term of the models (i.e., one GAM was created for each species per experimental month; i.e., Mytilus-August,
Mytilus-October, and Balanus-October) were done. This is a type III ANOVA, rather than a sequential type I ANOVA test (Wood, 2011). The figures are produced using ggplot2 (Wickham, 2016) and tidyverse (Wickham et al., 2019). GAM was chosen to be able to identify any non-linear (curvilinear or asymptotical) trends in cover over time (Hastie and Tibshirani, 1990).

Seawater temperature and salinity were registered both in August and in October.

\section{RESULTS}

The temperature was $20-21^{\circ} \mathrm{C}$ and $12^{\circ} \mathrm{C}$ in August and October, respectively, whereas salinity was 20 psu in August and 25 psu in October.

In the August study, the initial coverage of small blue mussels was $100 \%$ on all boulders, while it was around $40-50 \%$ in October. Both predators were observed to be feeding on the mussels within short time. In both experiments, the cover of mussels was reduced to almost zero within $24 \mathrm{~h}$ in all mesocosms that received either crabs, fish or both predators (Figure 2). The cover of blue mussels declined most rapidly in the mesocosms with both predator species present, followed by the mesocosms with crabs and then the ones with fish alone. With both predator species present, the cover was reduced to zero within $5 \mathrm{~h}$ in both August and October. The Wald tests revealed a significant effect of treatment and of the interaction between treatment and time, for each of the three GAMs (Table 1). All smooth terms of the treatment levels vs. time showed a significant decline in cover over time for each GAM, except for the controls in October (both species) and for $B$. improvisus in the fish treatment. There was a small, but significant predation effect in the control mesocosms in August due to the walkover by one crab in each of the two Controls (the smooth term of the treatment level Control vs. time was significantly different from zero in the Mytilus-August GAM; $F=8.1, p=0.005$, Table 1). However, no predation effect was observed in the control mesocosms in October (i.e., the smooth term of the treatment level Control vs. time was not significant in the Mytilus-October GAM).

The barnacles were observed to be eaten only by the crabs (Figure 3); this is confirmed by the fact that the smooth term of the treatment level Fish vs. time was not significantly different from zero in the Balanus-October GAM (Table 1). The consumption of barnacles took mainly place after an initial decline in mussels (mainly after $5 \mathrm{~h}$ ). As for the mussels, the crabs were able to reduce/consume the provided barnacles within $24 \mathrm{~h}$.

All models performed well and explained a substantial part of the variation in cover over time and between treatments. The explained deviance was above $70 \%$ for all GAMs (Table 1).

Only a smaller fraction of the total mesopredator individuals present in each mesocosm was observed to attack the blue mussels on the boulders. Only rarely, more than 5 crabs or 10 fish individuals were observed to be actively feeding on the mussels at a single occasion. Our own observations of the development of the blue mussel recruitment events in the fjord outside the 


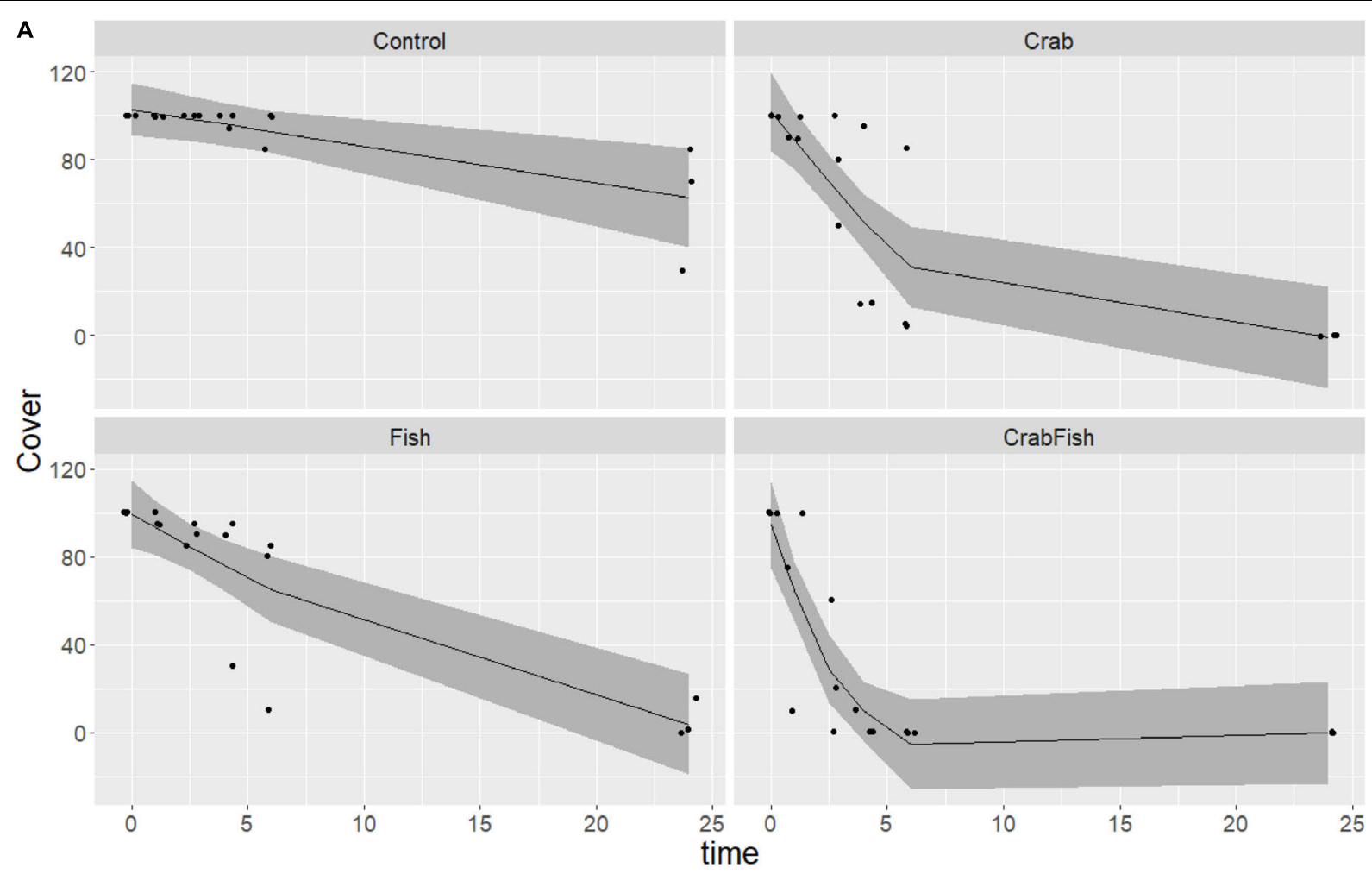

B

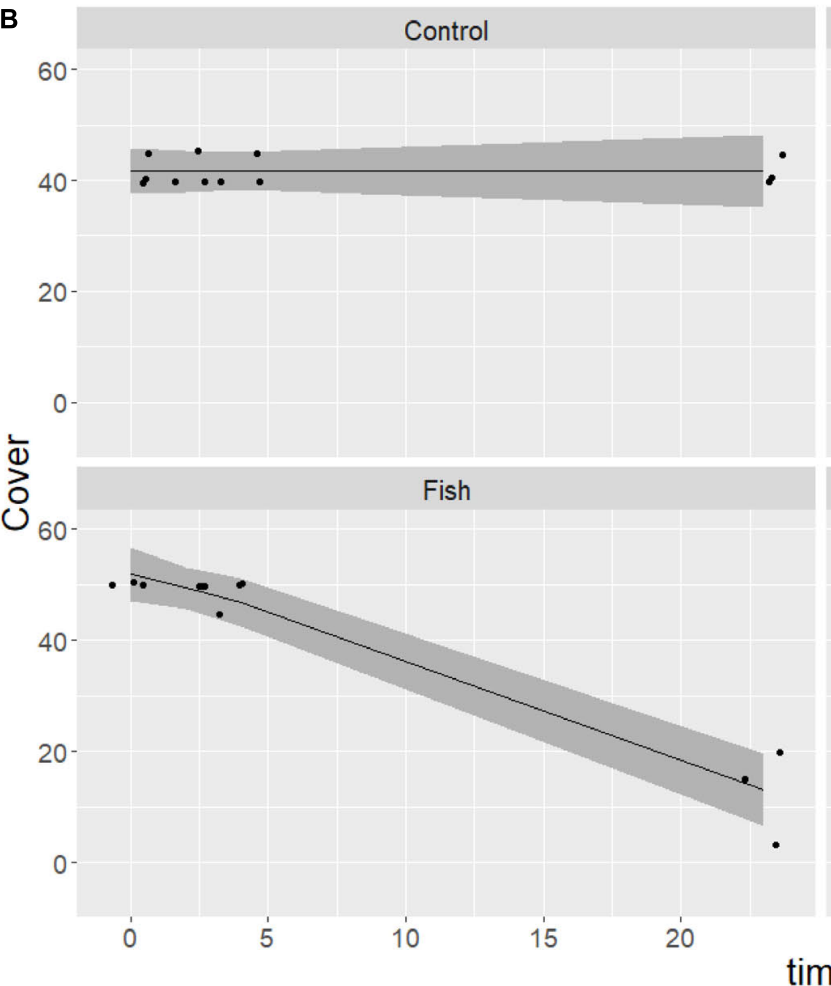

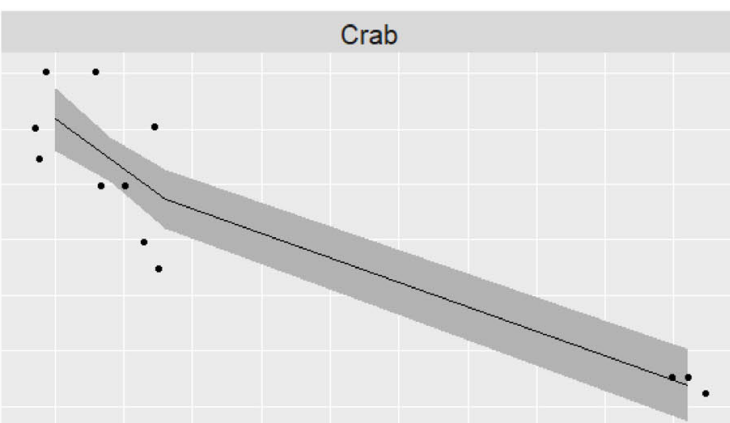

CrabFish

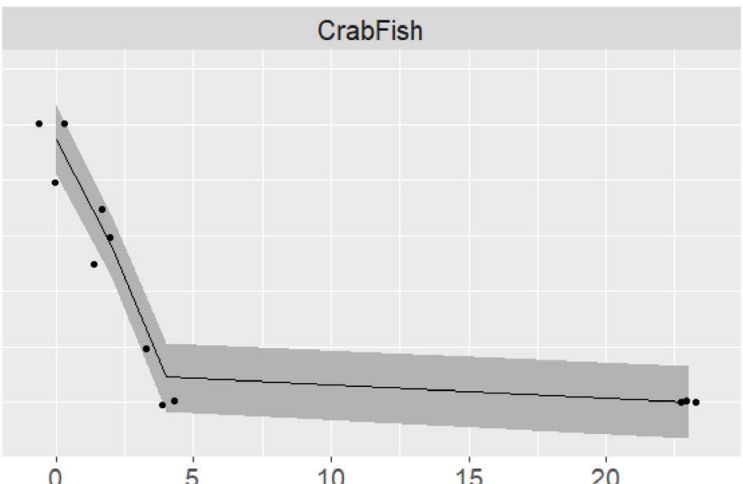

FIGURE 2 | Predicted and observed development in M. edulis cover over time in a $24 \mathrm{~h}$ experiment in August (A) and in October (B) 2019, given four different treatments (Control: no predators added, Crab: only crabs added as predator, Fish: only fish added as predator, CrabFish: i.e., both crabs and fish added as predator species to the mesocosms). The shaded area shows the $95 \%$ confidence levels of the predicted GAM values (i.e., cover as a function of treatment + time $\times$ treatment) and the points represent the observed cover at different times. There were always three replicates, and some overlapping points are not visible. 
TABLE 1 | Summary of the three GAMs performance; i.e., R-square adjusted and explained deviance, and the results of the Wald test of each model.

Mytilus August model (R-sq. adj $=0.77$, dev. explained $=80.3 \%, n=72)$

\begin{tabular}{|c|c|c|c|c|}
\hline Parametric terms & & df & $\mathbf{F}$ & $p$-value \\
\hline Treatment & & 3 & 27.47 & $2.4 \mathrm{E}-11$ \\
\hline Approximate significance of smooth terms & edf & Ref.df & $\mathbf{F}$ & $p$-value \\
\hline s(time):TreatmentControl & 1 & 1.001 & 8.125 & 0.00591 \\
\hline s(time):TreatmentCrab & 2.106 & 2.327 & 22.769 & 6.27E-09 \\
\hline s(time):TreatmentCrabFish & 2.631 & 2.871 & 18.302 & 5.92E-09 \\
\hline s(time):TreatmentFish & 1.561 & 1.831 & 25.862 & 8.79E-08 \\
\hline
\end{tabular}

Mytilus October model (R-sq adj $=0.91$, dev. explained $=92.5 \%, n=48$ )

\begin{tabular}{|c|c|c|c|c|}
\hline Parametric Terms & & df & $\mathbf{F}$ & $p$-value \\
\hline Treatment & & 3 & 35.84 & $4.52 E-11$ \\
\hline Approximate significance of smooth terms & edf & Ref.df & $\mathbf{F}$ & $p$-value \\
\hline s(time):TreatmentControl & 1 & 1 & 0 & 1 \\
\hline s(time):TreatmentCrab & 1.809 & 2.038 & 60.77 & $<2 e-16$ \\
\hline s(time):TreatmentCrabFish & 2.582 & 2.835 & 45.53 & $<2 e-16$ \\
\hline s(time):TreatmentFish & 1.355 & 1.59 & 60.58 & $2.03 \mathrm{E}-12$ \\
\hline
\end{tabular}

Balanus October model (R-sq. adj $=0.67$, dev. explained $=71.8 \%, n=48$ )

\begin{tabular}{|c|c|c|c|c|}
\hline Parametric Terms & & df & $\mathbf{F}$ & $p$-value \\
\hline Treatment & & 3 & 7.83 & 0.000316 \\
\hline Approximate significance of smooth terms & edf & Ref.df & $\mathbf{F}$ & $p$-value \\
\hline s(time):TreatmentControl & 1 & 1 & 0 & 1 \\
\hline s(time):TreatmentCrab & 1 & 1 & 29.94 & 1.84E-06 \\
\hline s(time):TreatmentCrabFish & 1 & 1 & 48.63 & 5.53E-09 \\
\hline s(time):TreatmentFish & 1 & 1 & 0 & 1 \\
\hline
\end{tabular}

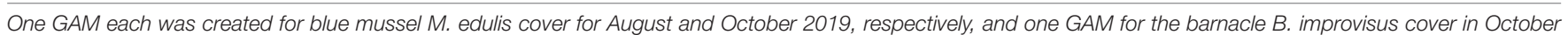

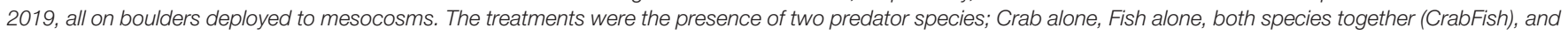

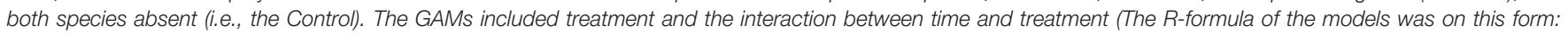
Cover $\sim s($ time, $b s=$ "cr," by $=$ Treatment, $k=4, m=1)+$ Treatment +1$)$.

research station, indicated a total disappearance of small mussels during a few weeks in August 2019. One month after the second recruitment in October, only a few small blue mussels were observed to remain in the uppermost parts of the intertidal zone, while the rest of the mussels was gone.

\section{DISCUSSION}

This pilot experiment shows the predation efficiency of two common mesopredator species, the goldsinny wrasse and the green crab, and their ability to reduce high and intermediate cover of small blue mussels to local extinction during a very short time period (within hours). The green crabs were most efficient in removing the blue mussels (as well as the barnacles), while the wrasses only predated on the mussels. Both species introduced together was the most efficient predator combination on blue mussel abundance. Hence, the presence of the other predator did not hamper the predation activity of either of the two predator species. On the contrary, when the crabs started to crush the mussels in the "CrabFish" treatments, this activity attracted the wrasses, probably due to some chemical cues. Thus, there was a co-consumption by the two species making the mussel reduction more efficient on the boulders than what was possible by consumption by either crabs or fish alone. The crabs preferred the small mussels, and they started to eat the barnacles first after most mussels were consumed. The low interest in barnacles among the wrasses are in accordance with gut content analysis by Kraufvelin et al. (2020), revealing small blue mussels to be their preferred prey organisms.

The two experiments (in August and October 2019) were performed in large littoral mesocosms with diverse natural seaweed ecosystems, where the predators had sufficient access to alternative prey items such as gastropods, amphipods, isopods, polychaetes and other invertebrates (Kraufvelin et al., 2002, 2006a,b, 2010, 2020; Bokn et al., 2003; Díaz et al., 2012). The rapid attraction to and predation on mussels by the two predator species within these mesocosms, indicate a high preference of juvenile blue mussels as prey. However, only between 5 and 20\% 


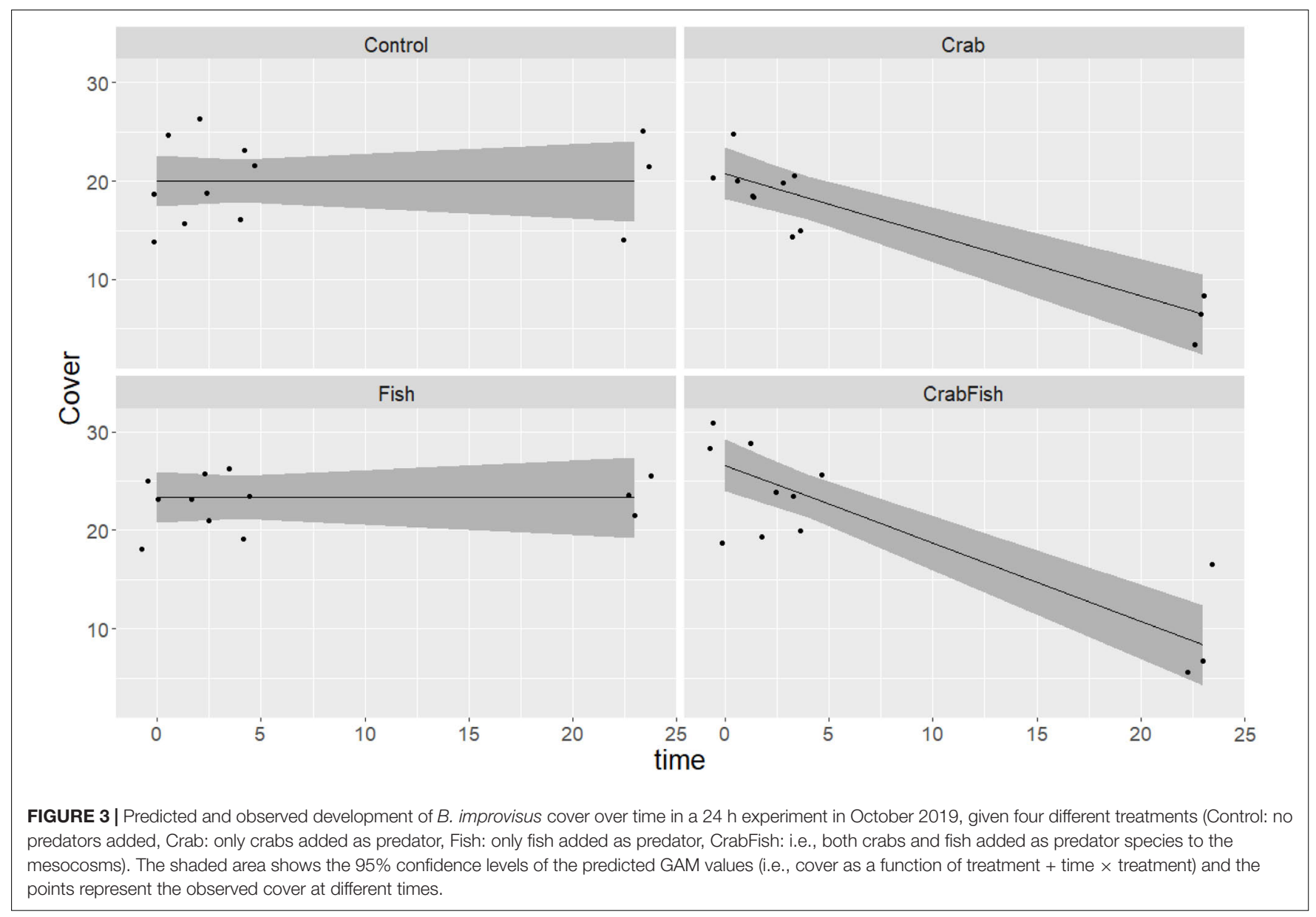

of the predators present in the mesocosms were observed in close proximity to the stones with mussels.

Many different predators are known to prey on blue mussels. The common starfish (Asterias rubens) is an important predator on adults and recruits of blue mussels in the NE Atlantic (see Hiscock et al., 2019) and also the eider duck, Somateria mollissima (Bustnes and Erikstad, 1990; Westerbom et al., 2002) is an important predator. Our experiment suggests that increasing populations of other small predators such as the green crab and the goldsinny wrasse may cause a severe threat to blue mussel beds/reefs and especially to mussel recruitment. This is primarily because of their preference of juvenile blue mussels as prey and their efficiency as predators preventing recruitment to larger size groups. In particular, the co-consumptive effect of the two predators might increase this threat. Recent observations of high mortality of hundreds of starved eider ducks in south Norway in winter/spring 2020, reported through media, has been suggested to be caused by a lack of larger blue mussels. This highlights the need to understand the role of these mesopredators for the structure and function of coastal ecosystems.

Top-down cascade effects favoring small mesopredators, such as small fish and crabs, are likely initiated because of reduced number and size of top predators and may cause significant community changes. Moksnes et al. (2008) and
Östman et al. (2016) reported similar effects of small fish in natural environments, and Kraufvelin et al. (2020) in mesocosms. Furthermore, this study supports the wide attention on increasing top down control by different crab species due to reductions of other populations of top predators (Hughes et al., 2013; Fagerli et al., 2014; Infantes et al., 2016; Christie et al., 2019). As our study indicates, increasing predator abundance is expected to lead to increased predation that affects particularly preferred prey organism as mussels. Rilov and Schiel (2006) describe a similar scenario where increased densities of crabs and wrasses caused increasing decline in juvenile mussels. As higher mesopredator population densities are expected to cause increased predation effects, the level of mesopredator increase in an area may be crucial for continued existence or extinction of mussel beds/reefs. As blue mussel beds create habitats for diverse communities (Norling and Kautsky, 2007; Díaz et al., 2015; Norling et al., 2015; Westerbom et al., 2019), changes in predator population levels may lead to large structural and functional changes in shallow reef ecosystems.

The field observations indicate that $M$. edulis can settle and recruit during several seasons (see also Bayne, 1964), with the potential of avoiding predation pressure at least during some of the recruitment events. However, our experiment showed high mesopredator activity in both summer and autumn by two 
predators that quickly can change from other prey organisms to small mussels. Also, our field observations indicate efficient predation on mussel recruits in the natural environment within a few weeks. In addition to green crabs and the goldsinny wrasse that both have become more abundant in this area (Gjøseter and Paulsen, 2004; Eriksson et al., 2011; Bergström et al., 2016; Infantes et al., 2016), other species of small fish, hermit crabs (Pagurus sp.), sea stars (A. rubens), and eider ducks (S. mollissima, although on larger size classes) are relevant blue mussel predators in the area, further increasing the predator pressure. Our experiment highlights the importance and efficiency of boosted mesopredator density on blue mussel mortality, but it cannot exclude the contribution from other predators and factors for the recent decreases in blue mussel abundance on rocky shores of the eastern North Sea.

\section{DATA AVAILABILITY STATEMENT}

The datasets generated for this study are available on request to the corresponding author.

\section{ETHICS STATEMENT}

The experiments fully comply with ethical standards and the experiments have received permission from the Norwegian Food Safety Authorities / Food and Animal authorities in Norway.

\section{REFERENCES}

Andersen, S., Grefsrud, E. S., Mortensen, S., Naustvoll, L. J., Strand, Ø, Strohmeier, T., et al. (2016). Reports on Disappearing Blue Mussels - Summing up for 2016. Norwegian: Institute of Marine Research.

Baden, S., Emanuelsson, A., Pihl, L., Svensson, C. J., and Åberg, P. (2012). Shift in seagrass food web structure over decades is linked to overfishing. Mar. Ecol. Prog. Ser. 451, 61-73. doi: 10.3354/meps09585

Bayne, B. (1964). Primary and secondary settlement in Mytilus edulis L. (Mollusca). J. Anim. Ecol. 33, 513-523.

Bergström, L., Karlsson, M., Bergström, U., Pihl, L., and Kraufvelin, P. (2016). Distribution of mesopredatory fish determined by habitat variables in a predator-depleted coastal system. Mar. Biol. 163: 201. doi: 10.1007/s00227-0162977-9

Bokn, T. L., Duarte, C. M., Pedersen, M. F., Marbá, N., Moy, F. E., Barrón, C., et al. (2003). The response of experimental rocky shore communities to nutrient additions. Ecosystems 6, 577-594. doi: 10.1007/s10021-002-0108-6

Brooks, S. J., and Farmen, E. (2013). The distribution of the mussel Mytilus species along the Norwegian coast. J. Shellfish Res. 32, 265-270.

Bustnes, J. O., and Erikstad, K. E. (1990). Size selection of common mussels, Mytilus edulis, by common eiders, Somateria mollissima: energy maximization or shell weight minimization? Can. J. Zool. 68, 2280-2283. doi: 10.1139/ z90-318

Cardinale, M., and Svedäng, H. (2004). Modelling recruitment and abundance of Atlantic cod, Gadus morhua, in the eastern SkagerrakKattegat (North Sea): evidence of severe depletion due to a prolonged period of high fishing pressure. Fish. Res. 69, 263-282. doi: 10.1016/j.fishres.2004.04.001

Christie, H. (1983). Use of video in remote studies of rocky subtidal community interactions. Sarsia 68, 191-194. doi: 10.1080/00364827.1983.10420571

Christie, H., Gundersen, H., Rinde, E., Filbee-Dexter, K., Norderhaug, K. M., Pedersen, T., et al. (2019). Can multitrophic interactions and ocean warming influence large scale kelp recovery? Ecol. Evol. 9, 2847-2862. doi: 10.1002/ece3. 4963
All applicable international, national (Norwegian Food Safety Authorities) and institutional guidelines for the care and use of animals were followed.

\section{AUTHOR CONTRIBUTIONS}

All authors were involved in field activities, in contributing to the manuscript, and giving approval for publication of this manuscript. HC had the lead in writing and ER the lead of the statistical analysis and figures.

\section{FUNDING}

The mesocosm part of this work was funded by internal money from the Norwegian Institute for Water Research (NIVA) and by the EU network of mesocosm facilities AQUACOSM (https://www.aquacosm.eu/). PK also received financial support from Svenska Litteratursällskapet i Finland r.f. (Ingrid, Margit och Henrik Höijers Donationsfond II).

\section{ACKNOWLEDGMENTS}

We are grateful to Oddbjørn Pettersen, Per Ivar Johannessen, and Per Kristian Ekern for excellent regular maintenance of the Solbergstrand mesocosms.

Díaz, E. R., Erlandsson, J., Westerbom, M., and Kraufvelin, P. (2015). Depth-related spatial patterns of sublittoral blue mussel beds and their associated macrofauna diversity revealed by geostatistical analyses. Mar. Ecol. Prog. Ser. 540, 121-134. doi: $10.1002 /$ ecs 2.2883

Díaz, E. R., Kraufvelin, P., and Erlandsson, J. (2012). Combining gut fluorescence technique and spatial analysis to determine Littorina littorea grazing dynamics in nutrient-enriched and nutrient-unenriched littoral mesocosms. Mar. Biol. 159, 837-852. doi: 10.1007/s00227-0111860-y

Eggermont, M., Bossier, P., Pande, G. S. J., Delahaut, V., Rayhan, A. M., Gupta, N., et al. (2017). Isolation of Vibrionaceae from wild blue mussel (Mytilus edulis) adults and their impact on blue mussel larviculture. FEMS Microbiol. Ecol. 93: fix039. doi: 10.1093/femsec/fix039

Elner, R. W. (1978). The mechanics of predation by the shore crab, Carcinus maenas (L.), on the edible mussel, Mytilus edulis L. Oecologia 36, 333-344. doi: 10.1007/bf00348059

Eriksson, B. K., van Sluis, C., Sieben, K., Kautsky, L., and Råberg, S. (2011). Omnivory and grazer functional composition moderate cascading trophic effects in experimental Fucus vesiculosus habitats. Mar. Biol. 158, 747-756. doi: 10.1007/s00227-010-1602-6

Fagerli, C. W., Norderhaug, K. M., Christie, H., Pedersen, M. F., and Fredriksen, S. (2014). Predators of the destructive sea urchin grazer (Strongylocentrotus droebachiensis) on the Norwegian coast. Mar. Ecol. Prog. Ser. 502, 207-218. doi: 10.3354/meps10701

Frigstad, H., Andersen, G. S., Trannum, H. C., Naustvoll, L.-J., Kaste, $\varnothing$, and Hjermann, D. $\varnothing$ (2018). Synthesis of Climate Relevant Results From Selected Monitoring Programs in the Coastal Zone. Part 2: Quantitative analyses. Norwegian: Norwegian Environment Agency.

Gjøseter, J., and Paulsen, Ø (2004). Strandnotundersøkelser på Skagerrakkysten 2003. Bergen: Institute of Marine Research.

Gjøsæter, J. (2002). Fishery for goldsinny wrasse (Ctenolabrus rupestris) (Labridae) with pots along the Norwegian Skagerrak coast. Sarsia 87, 83-90. doi: 10.1080/ 003648202753631767 
Green, N. W., Schøyen, M., Hjermann, D. Ø, Øxnevad, S., Ruus, A., Lusher, A., et al. (2018). Contaminants in Coastal Waters of Norway 2017. Bergen: Institute of Marine Research.

Hastie, T., and Tibshirani, R. (1990) . Generalized Additive Models. London: Chapman and Hall, 352.

Hastie, T., Tibshirani, R., and Friedman, J. (2009). The Elements of Statistical Learning: Data Mining, Inference and Prediction. Berlin: Springer.

Hiscock, K., Christie, H., and Bekkby, T. (2019). "The ecology of the rocky subtidal habitats of the Northeast Atlantic," in Interactions in the Marine Benthos: Global Patterns and Processes, eds S. J. Hawkins, K. Bohn, L. B. Firth, and G. A. Williams (Cambridge: Cambridge University Press).

Hughes, B. B., Eby, R., VanDyke, E., Tinker, M. T., Marks, C. I., and Johnson, K. S. (2013). Recovery of a top predator mediates negative eutrophic effects on seagrass. PNAS 110, 15313-15318. doi: 10.1073/pnas.1302805110

Infantes, E., Crouzy, C., and Moksnes, P.-O. (2016). Seed predation by the shore crab Carcinus maenas: a positive feedback preventing eelgrass recovery? PLoS One 11:e0168128. doi: 10.1371/journal.pone.0168128

Kraufvelin, P., Christie, H., and Gitmark, J. K. (2020). Top-down release of mesopredatory fish is a weaker structuring driver of temperate rocky shore communities than bottom-up nutrient enrichment. Mar. Biol. 167: 49.

Kraufvelin, P., Christie, H., and Olsen, M. (2002). Littoral macrofauna (secondary) responses to experimental nutrient addition to rocky shore mesocosms and a coastal lagoon. Hydrobiologia 484, 149-166. doi: 10.1007/978-94-017-31 90-4_13

Kraufvelin, P., Lindholm, A., Pedersen, M. F., Kirkerud, L. A., and Bonsdorff, E. (2010). Biomass, diversity and production of rocky shore macroalgae at two nutrient enrichment and wave action levels. Mar. Biol. 157, 29-47. doi: 10.1007/s00227-009-1293-z

Kraufvelin, P., Salovius, S., Christie, H., Moy, F. E., Karez, R., and Pedersen, M. F. (2006b). Eutrophication-induced changes in benthic algae affect the behaviour and fitness of the marine amphipod Gammarus locusta. Aquat. Bot. 84, 199-209. doi: 10.1016/j.aquabot.2005.08.008

Kraufvelin, P., Moy, F. E., Christie, H., and Bokn, T. L. (2006a). Nutrient addition to experimental rocky shore communities revisited: delayed responses, rapid recovery. Ecosystems 9, 1076-1093. doi: 10.1007/s10021-005-0188-1

Lundström, K. (2020). "Blåmussla Mytilus edulis," in Fisk-Och Skaldjursbestånd I Hav Och Sötvatten 2019. Resursöversikt. (Göteborg: Havs- Och Vattenmyndighetens Rapport 2020:3), 34-37.

Moksnes, P.-O. (2002). The relative importance of habitat-specific settlement, predation and juvenile dispersal for distribution and abundance of young juvenile shore crabs Carcinus maenas L. J. Exp. Mar. Biol. Ecol. 271, 41-73. doi: 10.1016/s0022-0981(02)00041-2

Moksnes, P. O., Gullström, M., Tryman, K., and Baden, S. (2008). Trophic cascades in a temperate seagrass community. Oikos 117, 763-777. doi: 10.1111/j.00301299.2008.16521.x

Moy, F. E., and Christie, H. (2012). Large-scale shift from sugar kelp (Saccharina latissima) to ephemeral algae along the south and west coast of Norway. Mar. Biol. Res. 8, 309-321. doi: 10.1080/17451000.2011.637561

Norling, P., and Kautsky, N. (2007). Structural and functional effects of Mytilus edulis on diversity of associated species and ecosystem functioning. Mar. Ecol. Prog. Ser. 351, 163-175. doi: 10.3354/meps07033

Norling, P., Lindegarth, M., Lindegarth, S., and Strand, Å (2015). Effects of live and post-mortem shell structures of invasive Pacific oysters and native blue mussels on macrofauna and fish. Mar. Ecol. Prog. Ser. 518, 123-138. doi: 10.3354/meps11044

Östman, Ö, Eklöf, J., Eriksson, B. K., Olsson, J., Moksnes, P.-O., and Bergström, U. (2016). Top-down control as important as nutrient enrichment for eutrophication effects in North Atlantic coastal ecosystems. J. Appl. Ecol. 53, 1138-1147. doi: 10.1111/1365-2664.12654

Paine, R. T. (1966). Food web complexity and species diversity. Am. Nat. 100, 65-75. doi: $10.1086 / 282400$
Peteiro, L. G., Filgueira, R., Labarta, U., and Fernandez-Reiris, M. J. (2010). The role of fish predation on recruitment of Mytilus galloprovincialis on different artificial mussel collectors. Aquacult. Eng. 42, 25-30. doi: 10.1016/j.aquaeng. 2009.09.003

Prugh, L. R., Stoner, C. J., Epps, C. W., Bean, W. T., Ripple, W. J., Laliberte, A. S., et al. (2009). The rise of the mesopredator. BioScience 59, 779-791. doi: 10.1525/bio.2009.59.9.9

R Core Team (2019). R: A Language and Environment for Statistical Computing. Vienna: R Foundation for Statistical Computing.

Rilov, G., and Schiel, D. R. (2006). Trophic linkages across seascapes: subtidal predators limit effective mussel recruitment in rocky intertidal communities. Mar. Ecol. Prog. Ser. 327, 83--93.

Sayer, M. D. J., Gibson, R. N., and Atkinson, R. J. A. (1993). Distribution and density of populations of goldsinny wrasse (Ctenolabrus rupestris) on the west coast of Scotland. J. Fish Biol. 43, 157-167. doi: 10.1111/j.1095-8649.1993. tb01185.x

Seuront, L., Nicastro, K. R., Zardi, G. I., and Goberville, E. (2019). Decreased thermal tolerance under recurrent heat stress conditions explains summer mass mortality of the blue mussel Mytilus edulis. Sci Rep 9: 17498. doi: 10.1038/ s41598-019-53580-w

Skiftesvik, A. B., Blom, G., Agnalt, A. L., Durif, C. M., Browman, H. I., Bjelland, R. M., et al. (2014). Wrasse (Labridae) as cleaner fish in salmonid aquaculture The Hardangerfjord as a case study. Mar. Biol. Res. 10, 289-300. doi: 10.1080/ 17451000.2013.810760

van der Heide, T., Tielens, E., van der Zee, E. M., Weerman, E. J., Holthuisen, S., Eriksson, B. K., et al. (2014). Predation and habitat modification synergistically interact to control bivalve recruitment on intertidal mudflats. Biol. Conserv. 172, 163-169. doi: 10.1016/j.biocon.2014. 02.036

Weijerman, M., Lindeboom, H., and Zuur, A. (2005). Regime shifts in marine ecosystems of the North Sea and Wadden Sea. Mar. Ecol. Prog. Ser. 298, 21-39. doi: 10.3354/meps 298021

Westerbom, M., Kilpi, M., and Mustonen, O. (2002). Blue mussels, Mytilus edulis, at the edge of the range: population structure, growth and biomass along a salinity gradient in the north-eastern Baltic Sea. Mar. Biol. 140, 991-999. doi: 10.1007/s00227-001-0765-6

Westerbom, M., Kraufvelin, P., Erlandsson, J., Korpinen, S., Mustonen, O., and Díaz, E. (2019). Wave stress and biotic facilitation drive community composition in a marginal hard bottom ecosystem. Ecosphere 10: e02883.

Wickham, H. (2016). ggplot2: Elegant Graphics for Data Analysis. New York, NY: Springer-Verlag.

Wickham, H., Averick, M., Bryan, J., Chang, W., D’Agostino McGowan, L., François, R., et al. (2019). Welcome to the tidyverse. J. Open. Sourc. Softw. 4: 1686. doi: $10.21105 /$ joss. 01686

Wood, S. N. (2011). Fast stable restricted maximum likelihood and marginal likelihood estimation of semiparametric generalized linear models. J. R. Stat. Soc. B 73, 3-36. doi: 10.1111/j.1467-9868.2010.00 749.x

Conflict of Interest: The authors declare that the research was conducted in the absence of any commercial or financial relationships that could be construed as a potential conflict of interest.

Copyright (c) 2020 Christie, Kraufvelin, Kraufvelin, Niemi and Rinde. This is an open-access article distributed under the terms of the Creative Commons Attribution License (CC BY). The use, distribution or reproduction in other forums is permitted, provided the original author(s) and the copyright owner(s) are credited and that the original publication in this journal is cited, in accordance with accepted academic practice. No use, distribution or reproduction is permitted which does not comply with these terms. 